\title{
Analyzing THE PLACE FOR THE EVENT-type Metonymies from the Perspective of Negative Evaluative Factors
}

\author{
Analisando a colocação da metonímia \\ ("THE PLACE FOR THE EVENT") \\ objetivando a atenuação de situações \\ negativas
}

Nami Arimitsu*

Toyo University

Tokyo / Japan

\begin{abstract}
This paper has two objectives. First, by analyzing THE PLACE FOR THE EVENT-type metonymies, this paper points out that it is mainly negative events that are expressed by this type of metonymy. Second, this paper reveals the motivations of those THE PLACE FOR THE EVENT-type metonymies that express negative events. Metonymies are widely investigated along with the views of Lakoff and Johnson (1980), and their oppositional semantic aspects are pointed out by Voßhagen (1999). However, none of the previous studies focused on the nature of THE PLACE FOR THE EVENTtype metonymies from the perspective of negative evaluation, euphemism, and politeness. "Let's not let Thailand become another Vietnam" expresses the Vietnam War and all the tragedies behind it. Speakers refrain from expressing negative evaluative aspects from a euphemistic perspective and try to behave politely through hiding the exact expression, and listeners can also easily understand THE PLACE FOR THE EVENT-type metonymies that express negative events, since negative events are much more highly marked and intensified, as well as more prominent, than are positive ones.
\end{abstract}

KEYWORDS: negative events; metonymy; politeness; euphemism.

\footnotetext{
* arimitsu@toyo.jp

${ }^{1}$ This research is supported by JSPS KAKENHI (Grants-in- Aid for Scientific Research), Grant Number 23720253.
} 
RESUMO: Este artigo tem dois objetivos. Em primeiro lugar, por meio da análise de metonímias do tipo LUGAR PELO EVENTO, o estudo aponta que principalmente os eventos negativos são expressos por meio desse tipo de metonímias. Em segundo lugar, revela as motivações para esse tipo de metonímia que expressa eventos negativos.A metonímia foi amplamente pesquisada no quadro da teoria de Lakoff e Johnson (1980), e também seus aspectos semânticos de oposição foram abordados por Voßhagen (1999). Porém, nenhum desses estudos se concentrou na natureza da metonímia baseando-se na avaliação negativa, eufemismo e polidez. No exemplo, "Não vamos deixar a Tailândia se tornar um outro Vietnã," essa ideia expressa a Guerra do Vietnã e suas tragédias. Os falantes deixam de expressar os aspectos negativos a partir de uma perspectiva eufemística e tentam ser polidos, tentando ocultar a expressão exata. Desta forma, os ouvintes podem facilmente compreender o significado da metonímia LUGAR PELO ACONTECIMENTO, já que eventos negativos são muito mais marcados e mais proem;nentes do que eventos positivos

PALAVRAS-CHAVE: eventos negativos; metonímia; atenuação de situações negativas; eufemística.

\section{Metaphor, Metonymy, and Cognitive Linguistics}

A revolutionary work by Lakoff and Johnson (1980, p. 3) identified that metaphors are not a mere "device of poetic imagination and the rhetorical flourish a matter of extraordinary rather than ordinary language. ... We have found, on the contrary, that metaphor is pervasive in everyday life." Lakoff and Johnson's contribution was their identification of metaphors as an exact reflection of our conceptual system.

"Metonymy has been studied for at least two thousand years by rhetoricians, for two hundred years by historical semanticists, and for about ten years by cognitive linguists" (Nerlich and Clarke, 2001, p. 245). The book Metaphors We Live By by Lakoff and Johnson (1980) mainly deals with metaphors rather than metonymies, but they actually devoted all of Chapter 8 to writing about metonymies. They demonstrated various examples of metonymies and defined their function as "using one entity to refer to another that is related to it. This is a case of what we will call metonymy" (ibid., p. 35). According to them, the difference between metaphor and metonymy is as follows:

Metaphor and metonymy are different kinds of processes. Metaphor is principally a way of conceiving of one thing in terms of another, and its primary function is understanding. Metonymy, on the other hand, has primarily a referential function, that is, it allows us to use one entity to stand for another. But metonymy is not merely a referential device. It also serves the function of providing understanding (ibid., p. 36). 
Lakoff and Johnson did not consider semantic oppositions in terms of negation and negative evaluative factors, and this is the contributive objective and finding of this paper, which aims to reveal the influence of negative evaluative factors in metonymic expressions, which has not been fully pointed out before.

Many new arguments have been posed after Lakoff and Johnson (1980). For instance, Radden (2000) discusses what metonymic metaphors are and provides evidence for the assumption that at least some metaphors are grounded in metonymy. He gives the example of the following sentence: "Suddenly the pilot comes over the intercom," and asserts that "it may be interpreted metonymically in the sense that the pilot's voice comes over the intercom or it may be interpreted metaphorically in the sense that the pilot announces something over the intercom"(ibid., p. 93). He defines metonymy, metaphor, and metonymy-based metaphor as follows.

Metonymy: a mapping within the same conceptual domain Metaphor: a mapping of one conceptual domain onto another Metonymy-based metaphor: a mapping involving two conceptual domains which are grounded in, or can be traced back to, one conceptual domain (ibid., p. 93)

He says that "the great number of metaphors which could be traced back to a metonymic basis in this investigation unequivocally confirm this assumption" (ibid., p. 105). He gives four factors as the metonymic driving force behind metaphors: (i) a common experiential basis of the two metaphorical domains, (ii) the operation of implicature, (iii) category structure, and (iv) cultural models. His position is that the notion of metonymy-based metaphors retains the linguistic notion of conceptual metaphor.

In another and more evolved study, Barnden (2010) reexamines and discusses the distinction between metaphor and metonymy. He addresses differences, such as the similarity/contiguity distinction and the issue of whether source-target links are part of the message in metonymy or metaphor. In particular, he argues that "metaphorical links can always be used metonymically and regarded as contiguities, and conversely that two particular, central types of metonymic contiguity essentially involve similarity" (ibid., p. 1). His suggestion is that "no combination of the alleged differences addressed can serve cleanly to categorize source/target associations 
into metaphorical ones and metonymic ones," and also that "it can be more profitable to analyze utterances at the level of the dimensions involved in the differences than at the higher level of metaphor and metonymy as such" (ibid., p. 1). He introduces two historical and traditional grounds for differentiation, (i) that metaphor involves similarity, whereas metonymy involves contiguity or related notions of semantic/pragmatic connections (DIRVEN, 2002; JAKOBSON, 2002 [1956]; LODGE , 1977; NORRICK, 1981; NUMBERG, 1978; RIEMER, 2001; among others), and (ii) that metonymy preserves links to the source domain items as part of the message, whereas metaphor does not (DIRVEN, 2002; HASER, 2005; WARREN, 2002), and draws the conclusion "that these various possible grounds for differentiation do not, as currently conceived at any rate, provide a form distinction between metaphor and metonymy" (BARNDEN, 2010, p. 2). In his paper, section 2 is devoted to considering whether a distinction between metaphor and metonymy can be found in a distinction between similarity and contiguity. Section 3 discusses the extent to which source/target links are themselves kept as part of the messages conveyed by metaphorical or metonymic utterances. Section 4 mainly examines two further possible grounds for differentiation: the interaction with conceptual compartments, such as domains and frames, and the role of imaginary identification/ categorization of target items and/or source items. His view in section 2 is connected with this paper, and he states that "there is nothing to stop us regarding the metaphorical links traversed in (at least) referential metaphor as special cases of contiguity" (ibid., p. 10). He focuses on the phenomenon that representations (things that represent) and their representees (the things they represent) are often used to stand for each other in metonymy, and he uses the term representational metonymy (ibid., p. 11) to cover both directions of metonymy: REPRESENTATEE FOR REPRESENTATION and REPRESENTATION FOR REPRESENTEE. He uses this term from a different (or broader) perspective than Warren's (2006). He also proposed the term partitive metonymy to cover both WHOLE FOR PART and PART FOR WHOLE metonymy, and points out that contiguity involves similarity (and thus could be regarded as metaphorical). He draws the following conclusion:

Thus, a major conclusion from the discussion in this article is that instead of worrying about whether some utterance is metaphorical or metonymic, or even about how far the utterance is along a literal/ 
metonymic/metaphorical continuum it is, we should often be asking instead: What degree and type of similarity does it involve, if any? What sort of contiguity does it involve, if any? Does it involve link survival? Is the source item hypothetical, and in what way? Is there any imaginary identification? And so forth. Considering the dimensions in themselves helps to free us from a mindset that seeks clear-cut differences between metaphor and metonymy when they may not exist (ibid.:, p. 26).

This paper values the previous discussions about the metaphor and metonymy distinction (and its slippery distinction/connection), and what Radden and Barnden point out is obviously part of the nature of metonymy. In particular, the referential metonymies that Barnden introduces as examples are important to bear in mind ("the creampuff didn't even show up," "Finland lost the match," "Bush attacked Iraq," "the date 9/11 for some terrorist events," etc.), but he does not mention the salience of negative evaluative factors, the consideration from the point of politeness, nor the choice of expression in social interaction. On that basis, this paper focuses on the point that negative evaluative factors in the world have particular salience; therefore, some metonymic expressions are also favorably used from the politeness point of view. This paper considers the roles and influences of negative evaluative factors in metonymy, which have not been investigated so far.

As for the relationship between opposition and metonymy, Voßhagen (1999) greatly contributed to the analysis of semantic reversion. However, no previous study has focused on the nature of THE PLACE FOR THE EVENT-type metonymies from the viewpoint of negative evaluative factors, euphemism, and politeness, and this paper aims to (1) indicate that it is mainly negative events that are expressed by these types of metonymy and (2) to reveal the motivations behind these types of metonymy that express negative events.

In Lakoff and Johnson (1980, p. 35-40), the following examples are shown.

(1) The ham sandwich is waiting for his check. (= the person who ordered the ham sandwich)

(2) Acrylic has taken over the art world. (= the use of acrylic paint)

(3) Mrs. Grundy frowns on blue jeans. (= the wearing of blue jeans)

They state that when a waitress says (1), "she is not interested in the person as a person but only as a customer, which is why the use of such a 
sentence is dehumanizing" (ibid., p. 39). These authors divide metonymies into subcategories. In fact, various types of metonymy actually exist, the most basic of which is the THE PART FOR THE WHOLE-type metonymy.

\section{THE PART FOR THE WHOLE (ibid., p. 36, 38)}

(4) The automobile is clogging our highways. (= the collection of automobiles)

(5) We need some new blood in the organization. (= new people)

(6) We don't hire longhairs.

(7) The Giants need a stronger arm in right field.

This type of metonymy is sometimes particularly called synecdoche. Here, automobile means the collection of automobiles. New blood means new people. Longhairs mean people who have long hair. Stronger arm means a person who is good at throwing a ball. There are also many other expressions, such as "the kettle is boiling" which actually means the water in the kettle is boiling. All the expressions above are understandable when they are translated into Japanese. It is surprising and interesting that even though Japanese, unlike English and Portuguese, is a non-Indo European language, the same or similar expressions are found in these languages. This is one piece of evidence that our basic human cognitive ability is of the same or similar nature as that of all human beings in general, and languages are a reflection of our basic cognition of the environment through our embodied experiences. In the following sections, I introduce English, Japanese, and Portuguese metonymic expressions as examples in order to show that there seems to exist PLACE FOR THE NEGATIVE EVENT-type metonymy as an improved and more elaborate version of Lakoff and Johnson's PLACE FOR THE EVENT-type metonymy, at least cross-linguistically in these three languages.

THE FACE FOR THE PERSON (ibid., p. 37)

(8) She's just a pretty face.

(9) We need some new faces around here. 
The face is the most prominent component of the human body, and it represents the person as a whole. All of the expressions above are equivalent in Japanese. The face is one of the most pronounced elements among our body parts regardless of which language the person uses, since the face has many sensory organs, such as the eyes, nose, mouth, and ears, which are essential for human beings to live. The prominence of the face does not vary depending on the language.

\section{PRODUCER FOR PRODUCT (ibid., p. 38)}

(10) He bought a Ford.

(11) He's got a Picasso in his den.

Lakoff and Johnson (1980) state that "when we think of a Picasso, we are not just thinking of a work of art alone, in and of itself. We think of it in terms of its relation to the artist, that is, his conception of art, his technique, his role in art history, etc. We act with reverence toward a Picasso, even a sketch he made as a teen-ager, because of its relation to the artist" (ibid., p. 39). Their views are convincing, but it is possible to add more specifications. For example, when we say, "I love Chopin," this generally means Chopin's piano works. It seldom means the chamber music works of Chopin since Chopin composed only a few (actually four) pieces of chamber music, and it is obvious that his major works are for the solo piano. This example tells us that PRODUCER FOR PRODUCT can be specified as PRODUCER FOR MAJOR PRODUCT. Moreover, it is possible to assume that one may actually love certain historical figures through their works, even though they are already dead and one has never met them in person. In such a case, the utterance, "I love Chopin," is no longer metonymic, and the expression, Chopin, actually refers to the person himself and not to his works. There are also many other similar expressions. It can happen that "I like Vladimir Horowitz" means the person likes Horowitz's recordings rather than Horowitz himself. In this case, it is a metonymic expression. Barnden (2010, p. 3) states that "in principle, an expression should not be said to be metaphorical or metonymic in any absolute sense, but only for a particular user. Of course, in practice, many expressions may be metaphorical or metonymic for the vast majority of native users of a language, and the way 
in which expressions are metaphorical or metonymic may also be the same or similar across such users." Furthermore, Goossens (1995) points out that there are the expressions called metaphtonymy, and claims that metaphor and metonymy interact in conventionalized expressions where linguistic action is the target domain. He divided the types into three categories. The first type is (A) metaphor from metonymy, and there are expressions such as "Oh dear," she giggled, "I'd quite forgotten" (ibid., p. 164). The second type is (B) metonymy within metaphor, as indicated in expressions such as "I should / could bite my tongue off" (ibid., p. 170) The third type is (C) demetonymization inside a metaphor, shown through expressions such as "pay lip service" (ibid., p. 171). The expressions Chopin and Horowitz above could therefore be interpreted as metaphtonymy, since their meanings could even have metaphoric meanings, such as "a romantic boy in the class" or "a magic show that he/she enjoyed at a holiday destination."

\section{CONTROLLER FOR CONTROLLED (ibid., p. 38)}

(12) Nixon bombed Hanoi.

(13) Ozawa gave a terrible concert last night.

INSTITUTION FOR PEOPLE RESPONSIBLE (ibid., p. 38)

(14) Exxon has raised its prices again.

(15) The Senate thinks abortion is immoral.

Lakoff and Johnson (1980) state that "Nixon himself may not have dropped the bombs on Hanoi, but via the CONTROLLER FOR CONTROLLED metonymy, we not only say 'Nixon bombed Hanoi', but also think of him as doing the bombing and hold him responsible for it. Again this is possible because of the nature of the metonymic relationship in the CONTROLLER FOR CONTROLLED metonymy, where responsibility is what is focused on" (ibid., p. 39). As we can say both "Ozawa gave a great concert last night" and "Ozawa gave a terrible concert last night," CONTROLLER FOR CONTROLLED metonymy can be used to both praise and dispraise. CONTROLLER FOR CONTROLLED metonymy 
has the effect of highlighting the target with whom the positive/negative responsibility lies.

I found that these two metonymies, CONTROLLER FOR CONTROLLED and INSTITUTION FOR PEOPLE RESPONSIBLE are in an oppositional relationship. CONTROLLER FOR CONTROLLED tries to expose the person responsible for the event.

On the other hand, INSTITUTION FOR PEOPLE RESPONSIBLE tries to hide the person responsible for the event. People may choose a metonymic expression depending on the purpose of their utterance: whether to highlight and intensify the person responsible or to keep the profile of the person responsible as low as possible. These choices are made from the perspective of pragmatic intention.

\section{THE PLACE FOR THE INSTITUTION (ibid., p. 38)}

(16) Washington is insensitive to the needs of the people.

(17) The Kremlin threatened to boycott the next round of SALT talks.

(18) Paris is introducing longer skirts this season.

(19) Hollywood isn't what it used to be.

It seems that there is no fixed positive/negative evaluation for the interpretation of THE PLACE FOR THE INSTITUTION-type metonymies. Their positive/negative evaluation varies depending on the context. In the examples above, Washington and the Kremlin are examples of hiding the major persons in the institutions. On the other hand, it is possible to interpret expressions such as Paris, Hollywood, and Wall Street as a type of exaggeration, since not all the boutiques in Paris, or not all the fashion shows in Paris, are introducing longer skirts, nor have all the movie companies in Hollywood changed.

It should also be mentioned there are many other types of metonymy beyond those formulated by Lakoff and Johnson (1980). For example, I found that THE MATERIAL FOR THE OBJECT-type exists as well. 


\section{THE MATERIAL FOR THE OBJECT}

(20) Professor Maria Lúcia Coutinho Colen tickled the ivories.

(21) I got an amethyst for my birthday.

(22) Tirar a mesa (=to clear the table)

"To tickle the ivories" means to play the piano, since the white keys are made of ivory. When we say "I got an amethyst for my birthday" it does not mean that the person got an actual amethyst itself, but that the necklace or ring is made of or decorated with amethyst. This amethyst example is understandable both in English and Japanese when it is literally translated. "Tirar a mesa" is a THE PART FOR THE WHOLE-type metonymic expression that expresses clearing off the table, and interestingly, no literal translation exists in either English or Japanese.

In this section, I have overviewed general assumptions and previous studies concerning various types of metonymy. The following sections will focus on examples of THE PLACE FOR THE EVENT-type metonymies in order to fully analyze them, as well as point out that opposition and negative evaluations are crucial factors in expressing and interpreting metonymies.

\section{Opposition as a Metonymic Principle by Voßhagen (1999)}

Voßhagen provides an overview of his 1999 paper as follows:

This paper discusses the notion that forms of language use in which something is uttered to convey its opposite are metonymic. In this view, a conceptual entity can be used to provide mental access to its opposite, which is closely associated with it within a conceptual structure ... These factors will be discussed as motivations of metonymic mappings of one concept onto its opposite in figurative language including euphemism, socially motivated reversals, irony, and expressive use of negatives to convey positive evaluations (ibid., p. 289).

Voßhagen supports his view with the evidence of various colloquial expressions from the novel by Edward Albee (1962), Who's Afraid of Virginia Woolf, and many slang expressions from the dictionaries used in everyday conversation based on the opposition. 
Oppositional expressions and human cognition are inseparably related. Firstly, different types of oppositions exist. The major and basic distinction of opposition is contradictory (antonymous) and contrary. Contradictory (antonymous) opposition is not gradable, does not express degree of intensity, and does not have intermediary terms between the two polarities (for example, odd versus even), whereas contrary opposition is gradable, expresses a degree of intensity, and has intermediary terms between the two polarities (for example, big versus small). These oppositional relationships are essential not only for language, but also for psychological cognitive development in general. Thus, children learn to distinguish these semantically oppositional relations at an early stage of their development (Landis, Herrmann, and Chaffin, 1987).

Secondly, opposition plays an important role for metonymy. Voßhagen (1999) proposes the concept of opposition metonymy and specifies that this type of metonymy is only applicable to evaluative (connotative, for example, good and bad) rather than denotative (for example, big versus small) oppositions. Thus, Voßhagen's principle would be expressed as AN EVALUATIVE CONCEPT MAY STAND FOR ITS OPPOSITE. He points out the discrepancy between semantic and conceptual opposition. There seems to exist contrary opposition such as "good versus bad," which is gradable, expresses a degree of intensity, and has intermediary terms between the two polarities. However, as shown by the expressions he cites from Hayakawa (1978, p. 211), such as "the two sides of a story," "there are two sides to everything," "there is a thin line between love and hate," and "to think in black and white rather than in shades of gray" in usage, people actually see this kind of evaluative conceptual opposition as contradictory opposition and not as contrary opposition. According to Voßhagen (1999, p. 293-294), people interpret the evaluative opposition of "good versus bad" as a metonymic expression not as in (a) below, but more like (b), such as "dead versus alive."

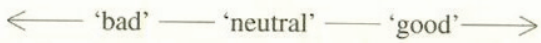

(a)

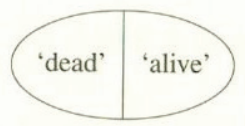

(b) 
In other words, we tend to see the evaluative factors contradictorily rather than contrarily, perhaps in my view, to simplify our understanding.

One aspect of euphemism and irony employs opposition, and the speaker utters a positive term to convey a negative evaluative factor. This bipolar view of things even for gradable evaluative factors, such as "good versus bad" allows people to convey and understand the expressions based on oppositional metonymy, in other words, the concept that AN EVALUATIVE CONCEPT MAY STAND FOR ITS OPPOSITE.

\section{THE PLACE FOR THE EVENT-type Metonymies from the Perspectives of Negative Evaluation}

Lakoff and Johnson (1980, p. 39) propose examples of THE PLACE FOR THE EVENT as shown below. However, they neither analyze the expressions from the perspective of negative evaluation nor look for their motivations on the grounds of euphemism and politeness.

\section{THE PLACE FOR THE EVENT (ibid., p. 39)}

(23) Let's not let Thailand become another Vietnam.

(24) Remember the Alamo.

(25) Pearl Harbor still has an effect on our foreign policy.

(26) Watergate changed our politics.

(27) It's been Grand Central Station here all day.

The expression Vietnam means the Vietnam War and all its accompanying woes. Alamo means the war at the Alamo, and both Pearl Harbor and Watergate are the wars and affairs that ended with negative results.

The last example, Grand Central Station, is completely different from the other examples above, since Grand Central Station is only the name of a large station, and it is neither an accident nor an event. It is a huge station in New York and is thus always crowded. They say that THE PLACE FOR 
THE EVENT is grounded in our experience with the physical location of events (ibid., p. 40). We can infer that the place is crowded just like Grand Central Station. Hence, it is possible to think that exaggerating expressions, such as "it's been a refrigerator (cold) / a sardine can (in a narrow space) / a kindergarten (noisy) here all day" are expressions based on THE PLACE FOR THE EVENT. However, refrigerator, sardine can, or kindergarten is not an event, but merely a place with some prominently negative characteristics or features. Therefore, this study can exclude the example of Grand Central Station from THE PLACE FOR THE EVENT-type metonymies in a later discussion or simply focus on the negative evaluative factor in the example of Grand Central Station. Again, it should be noted that the expressions Vietnam, Alamo, Pearl Harbor, and Watergate are alike, but the basis of Grand Central Station is completely different in its nature.

\subsection{Further Examples and THE PLACE FOR THE NEGATIVE EVENT- type Metonymy}

Many other creative examples exist not only in English, but also in Japanese and Portuguese. Here, this paper proposes the metonymy THE PLACE FOR THE NEGATIVE EVENT.

\section{THE PLACE FOR THE NEGATIVE EVENT}

\section{(28) Hiroshima, Nagasaki}

(29) Fukushima

(30) 203 koti

(31) We will never forget Maracanã / Mineirão.

(32) Em 1950 foi o Maracanaço, e ontem foi o Mineraço, um vexame (http://linhadefogo.wordpress.com/2014/07/09/em-1950-foi-o-maracanaco-e-ontem-foi-o-mineraco-um-vexame/)

(33) A vergonha do Maracanaço de 1950 acabou de ser apagada! \#Mineraço (July 9, 2014, Karine Vargas@karine_vargas ) 
(34) MARACANAÇO, CULTURA GERAL; MINEIRAÇO, SADISMOPURO (http://blogdopaulomayr.wordpress.com/2014/07/08/maracanaco-culturageral-mineraco-sadismo-puro/)

(35) Kobe

(36) Kono natu wa kimi no jinsei no sekigahara da! (This summer is the decisive battle in your life.)

It is surprising that most of these expressions are describing negative events.

Hiroshima and Nagasaki are two tragically symbolic places on which atomic bombs were dropped by the U.S. during the final stages of World War II in August 1945, and they were the first and only use of nuclear weapons in war. The result was horrific. Countless ordinary people from young to old involved in the war were killed by these two atomic bombs. The cities of Hiroshima and Nagasaki were totally demolished, and Japan was devastated. These two events are exceedingly prominent and unforgettable, and at the same time, this sorrow is so great that people cannot even describe the events in words, or people do not need concrete descriptions with words for these events. People can infer a similar cognitive process with the name Auschwitz. It is not just a place name; it represents everything horrific that happened at the Auschwitz concentration camp during World War II. These are large and inexpungible negative events in world history, and even ordinary people can imagine the intended meanings of these metonymic expressions.

After March 11, 2011, in Japan, the place name of Fukushima began to be used as a metonymic expression, and it now refers to the Great East Japan Earthquake that caused major destruction. It was the biggest and the most powerful earthquake in Japan. This earthquake caused powerful tsunami waves, and many residents in that region were killed. The tsunami waves also struck the Fukushima Daiichi Nuclear Power Plant complex and the associated evacuation zones, triggering nuclear radiation accidents that remain fully unresolved today. Before March 11, 2011, in Japan, when the place name Fukushima was used, it generally only referred to somewhere rural. For people who love to read about history, the name Fukushima would remind them of its old name, Aizu, and they would recall some historical events such as Byakkotai (White Tiger Corps). This is a tragic story in Japanese history. Byakkotai is the name of the group of teenage trainees from the Aizu (the old 
name for the Fukushima area) clan in the nineteenth century, and when they lost the Boshin War, these young solders committed suicide to protect their honor in line with the spirit of Bushido (the soul of Japan). However, before March 11, 2011, its interpretation was not as fixed as it is today. Today, the word Fukushima implies everything that happened there after the Great East Japan Earthquake on March 11, 2011, and there are frequent usages, such as Fukushima o kurikaesu/wasureru na! (Don't repeat/forget [the tragedy of] Fukushima). Since it was a major disaster with global impact, even nonJapanese people can understand the metonymic meaning of Fukushima. ${ }^{2}$

The metonymic expression 203 koti (203 Hill) might be less comprehensible than the above examples. This is the name of a district in Dalian City in China, fiercely contested by Japan and Russia during the RussoJapanese War in 1904-1905. It is named "203 koti (203 Hill)", as it is 203 meters above sea level. When Japanese people hear the words 203 koti, they

${ }^{2}$ I would not say that THE PLACE FOR THE NEGATIVE EVENT is the only metonymic expression to illustrate negative events. There are also other types. For example, THE NUMBER FOR THE NEGATIVE EVENT can also be found. Barnden (2010, p. 9) mentions the expression " $9 / 11$ " and states as follows from the point of view of contiguity:

There is a sense in which the partial isomorphism of structure really exists. It is a mathematical aspect of the world that exists just as much as a simple, familiar mathematical object such as the number 9 does. And, the partial isomorphisms exist just as much as the link between, say, the date $11^{\text {th }}$ September 2001 and certain terrorist events does. So, given that the dates and events are used metonymically for each other e. g., the (abbreviated) date $9 / 11$ for some terrorist events and given that their relationship is a contiguity, it seems artificial not to regard the abovementioned analogical links as contiguities.

In Japanese as well, Fukushima o kurikaesu/wasureru na! (Don't repeat/forget [the tragedy of] Fukushima.) can be replaced with 3.11 o kurikaesu/wasureru na! (Don't repeat/forget [the tragedy of] the date March $11^{\text {th }}$ ). As $9 / 11$ is pronounced "nine eleven," similarly in Japanese 3.11 is pronounced "san ten iti iti," which literally means "three point one one," and it is much more common than pronouncing it "san gatu juu iti niti," which literally means March $11^{\text {th }}$, when it is used to refer to the Great East Japan Earthquake. It can be regarded as a reflection of euphemism, which will be discussed in section 4 . 
do not interpret it as merely the name of a district, but rather as a brutal battle where many people died. The accuracy of interpretation and understanding of this expression largely depends on the hearer's background knowledge.

Maracana is the Portuguese name of the famous stadium in Rio de Janeiro, Brazil. It sometimes represents more than simply the name of the stadium, such as the historical World Cup football game between Brazil and Uruguay in 1950 that Brazil lost with heartbreaking disappointment. In Portuguese, this is called Maracanaço (meaning "the Maracanä blow"). Similarly, Mineirão is the Portuguese name of the prestigious stadium in Belo Horizonte, Brazil, and it now recalls a football match of the 2014 World Cup in which Brazil suffered a crushing defeat against Germany, which is now called Mineraço ("the Mineirão blow") in Portuguese. Games always have winners and losers, and their nature is totally different from that of wars. In addition, the World Cup is held in the world every four years, and the result is not interminable. It is more like a record in an eternal process rather than a oneand-only result. Therefore, people always have the potential to become a winner (or a loser) in the next World Cup. It means that if Brazil dramatically wins the game by a wide margin, and that game is held in Maracana or Mineirão, their metonymic expressions and interpretations would be different, and they would even have the potential to refer to a great victory, though negative events are more prominent than positive ones, and THE PLACE FOR THE EVENT-type metonymies are generally used to express negative events in history.

It is also worth pointing out that people change or weaken the recognition of a negative event as time passes.

A city in Japan, Kobe, experienced a terrible earthquake in 1999. People knew and know about that disaster very well, but as time has passed, and rebuilding and renovation have successfully proceeded, people have gradually lost their impression of the terrible earthquake. Thus, the metonymic expression Kobe now does not necessarily convey the meaning of "the earthquake that struck Kobe in 1999."

It is difficult to find positive events described by THE PLACE FOR THE EVENT-type metonymies. However, there are some exceptions. Sekigahara is neither negative nor positive; it is the name of the place where a major historical battle took place. After the battle, the Japanese society completely changed, since the ruler of the country changed. The Battle of Sekigahara led to the Shogunate of Tokugawa Ieyasu, and the Toyotomi clan lost its power after the battle. This is used in everyday expressions, such as Sekigahara no natsu (summer of Sekigahara), which means if you do 
not study hard during the summer vacation, you will fail the exam in the winter; in other words, you will lose the battle. Tenka wakame no Sekigahara (dividing the world into two parts into winners and losers) is also frequently used to encourage people to work hard or to win the game, otherwise losing the game will be the outcome. It is interesting to note that only the intensification of the battle now remains, and, for modern people, the battle itself has neither a positive nor negative evaluative value.

It is clear that these metonymic expressions are highly context-based, and people who have different cultural backgrounds will not understand their meanings.

\subsection{Revisiting Negativeness: What are Negative Events?}

There is the question of whether people really see the events illustrated through THE PLACE FOR THE NEGATIVE EVENT- metonymies as being negative. This paper shows empirical evidence that people do indeed see these events as being negative. In official school textbooks, historically named events are often negative or treat conflicts. I have checked and counted the chronological table of historically named events related to wars or conflicts in world history shown in one of the major high school history textbooks in Japan, entitled Shosetsu Sekaishi (Detailed World History) from Yamakawa Publishing Co. (1997). The total number of historically named events related to wars or conflicts is 118 , and the number of negative events related to wars or conflicts expressed via names of places is 72 . The rest (46) are expressions via names of people, times, purposes, and so on. It can be said that the number of negative events related to wars or conflicts expressed via names of places accounts for more than half of these types of negative events. Additionally, in a history book entitled History Year by Year, published by Dorling Kindersley in United Kingdom in 2011, there is a directory section and eight categories are shown. These include rules and leaders, history in figures, wars, explorers, inventions and discoveries, philosophy and religion, culture and learning, and disasters. In other words, they are positive evaluative achievements and negative evaluative events. In particular, concerning wars, this book states that "the human story is one of conflict. Disputes over territory, religion, and governance have escalated into war throughout history, and while the stories of great battles and great commanders make compelling reading, the tragic consequences of war should never be forgotten" (Nanney 2011, p. 480). In this book, 23 out of 
42 major wars are expressed via the names of places, such as the Afghanistan War or the Crimean War. The major wars expressed via the names of people (for example, the Napoleonic Wars) or the length of the wars (for example, the Hundred Years War) are the minority. Concerning disasters, the book also states that "few civilizations have been immune to the effects of natural disasters, which have sometimes killed hundreds of thousands, or even in the case of plagues, many millions of people. Disasters such as the eruption of Pompeii, the Antioch earthquake of $526 \mathrm{CE}$ and the Black Death caused huge loss of life, but modern societies are no less vulnerable, as evidenced by the loss of life in the 2004 Indian Ocean and 2011 Japanese tsunamis" (ibid., p. 488). Wars, earthquakes, volcanic eruptions, floods, famines, epidemics, and plagues have as strong an impact as positive evaluative great achievements do. Thus, these negative evaluative events are also selected and treated in as equally an important manner in the book as are positive evaluative great achievements that people should not, and cannot, forget.

First of all, events consist of certain factors: they are "when," "where," "who," "what," "why," and "how." Other interrogative words such as "which," "whose," etc. can be added, but the first five factors are essential to composing an account of events. From the historian's viewpoint, it is not generally reasonable to name events by using the expression reflecting the time "when," since history is a continuum of time, and it would be hard to distinguish, memorize, and recall an event by the naming of time. Choosing expressions related to "what," "why," and "how" would sometimes be too self-explanatory, but adopting expressions related to "where" and "who" would be wellabbreviated and highlighted. However, it would be reasonable to have timenaming for a historical event on some occasions. In Japan, at the end of the Edo period, major political events took place in Kyoto. After the Meiji Restoration, major political events occurred in Tokyo. Therefore, it would be complicated and less meaningful to choose place names for events, and choosing dates for event names is more than opting for place names as event names.

It is also important to point out who named the events. After the appearance of mass media, journalism, such as that found in newspapers and magazines, named events as they saw fit. Today, in Japan, the Japanese government checks the expressions used in school textbooks and, of course, names for events are carefully and officially chosen. Therefore, names are somewhat biased towards the viewpoint of the people who choose them. For example, war itself can be said to be negative, since it represents a conflict between two sides, and there is potential death or at least a potentially 
negative result for both sides. War changes the world and leads to people's deaths. If one thinks that to live is the best outcome for animals, including human beings, and to be killed or to die is the worst, war can be seen as a negative evaluative event. History is composed of wars. People who would benefit from the same things flock together, but people who would benefit from different things, or who are oppressed or in a position of surrender, will seek the chance to better their position. Conflicts are therefore created, since there are opposing views. As wars generally have a win/lose result, the end of a war tends to have a negative meaning for some people and a positive one for others, even though the nature of war itself is negative. In Japan, many people are taught to call the day August 15, 1945, as shuusen no hi, which literally means "the day of the end of the war." There are some people who claim that we should name it haisen no hi, which literally means "the day of losing the war." On the other hand, in Korea, they call the same day gwangbokjeol, which literally means "return of the light." This represents is Korea's day of independence from Japan. The question above is insightful, since it makes us consider what negative events are and whether they are truly negative or not. The answer is that people can evaluate historical events according to their backgrounds and where they belong, but the nature of war and conflict is basically negative evaluative, since it can directly lead to the death of human beings, which is the worst outcome for all animals, including human beings.

Some synchronic factors exist as well. In 2014, in Japan, murders were committed in Kobe and Sasebo. There was intense media coverage in the news, so people could automatically infer the meaning of "the case in Kobe" or "the case in Sasebo" as murderous acts that had recently happened. In these cases, Kobe would not indicate the terrible earthquake that attacked Kobe and the Hanshin area in 1995. Therefore, the interpretation of metonymic expressions of this kind is highly context based.

The next section further investigates the motivations for using metonymic expressions for negative events.

\section{Motivations for Choosing THE PLACE FOR THE EVENT-type Metonymies Expressing Negative Events}

Expressions of THE PLACE FOR THE EVENT-type metonymies is a reflection of the fact that we can employ markedness of negation/ negativeness for intensification. In order to convey the intended meaning of a metonymic expression, intensified prominence of the target is essential. 
For THE PLACE FOR THE EVENT-type metonymies, negative evaluation is the key factors serving as intensified prominence.

The markedness of negation/negativeness has been indicated for many years. In linguistics, it has been stated since Jespersen (1917), who explains the change of the pattern in languages as follows:

The history of negative expression in various languages makes us witness the following curious fluctuation: the original negative adverb is first weakened, then found insufficient and therefore strengthened, generally through some additional word, and this in turn may be felt as the negative proper and may then in the course of time be subject to the same development as the original word (ibid., p. 4).

Horn (1989, p. 457) also considers the motivation for this cyclic change as follows: "But if word order is not a crucial factor (or at least not the crucial factor in motivating Jespersen's cycle), what is? Jespersen's answer is clear from his description of the cycle: an unstressed monosyllabic syllable consisting of nasal + neutral vowel is simply too weak to serve as the conduit for the vital function with which it has been entrusted, that of differentiating a positive statement from its contradictory" and further supports his statement by citing Jespersen (1917).

The negative notion, which is logically very important, is ... made to be accentually subordinate to some other notion; and as this happens constantly, the negative gradually becomes a mere proclitic syllable (or even less than a syllable) prefixed to some other word. The incongruity between the notional importance and the formal insignificance of the negative may then cause the speaker to add something to make the sense perfectly clear to the hearer. (ibid., p. 5)

This cyclic process of change has specific names, such as the negative cycle, Jespersen's cycle, and the Jespersen cycle, as named by Darl (1979). However, there are variations in dividing the change into stages (JESPERSEN, 1917; HORN, 1989; LADUSAW, 1993).

\section{(37) Negative Cycle}

Stage I:

Jeo ne dis. (Old French)

I NEG say

I do not say. 
Stage II: Both preverbal and postverbal elements are obligatory.

Je ne dis pas. (Modern standard French)

I NEG say NEG

I do not say

Stage III: The original preverbal element becomes optional or is lost altogether.

Je dis pas. (Modern colloquial French)

I say NEG

I do not say

A similar change is found in English as well (Horn, 1989, p. 455).

Old English: Ic ne secge.

Middle English: Ic ne seye not.

Early Modern English: I say not.

Jespersen (1917) states that "such reinforcement also serves 'to increase the phonetic bulk of negative" (ibid., p.14), and continues 'to make the negative more impressive as being more vivid of picturesque, generally through an exaggeration, as when substantives meaning something very small are used as subjuncts' (ibid., p. 15).

In other words, the negative cycle shows the proximity and uniformity of positive and negative. Positive and negative seem to be in a complete opposition and are actually an opposition. Positive consists of one pole and negative consists of the other pole. These two oppositional polarities seem the farthest from each other, but, in fact, they are two sides of the same coin and are inextricably linked together.

From a psychological perspective, according to Ekman et al. (1983), certain negative emotions are experienced more intensely than positive ones; in particular, physiological effects, such as heart rate, seem to increase more through the negative emotions of fear and anger than through the positive emotion of happiness. Voßhagen (1999, p. 304) states that "negative emotion concepts are, paradoxically, very suitable for the expression of highly positive concepts." Jing-Schumidt (2007) also examines negative emotive expressions and their change into intensifiers. 


\subsection{Using Euphemism for Politeness}

Euphemisms can be used in various ways and for various purposes.

\section{OBJECT USED FOR USER (ibid.: 38)}

(39) The sax has the flu today.

(40) The BLT is a lousy tipper.

Here, the sax means the sax player. The BLT means the customer who ordered the bacon, lettuce, and tomato sandwich. This type is more context-based than other types of metonymy. It is sometimes difficult for the outsider to fully understand the intended interpretation. For people who are not working at the same cafeteria, it is quite difficult to understand what $B L T$ means. Therefore, it has some similarities to secret code language. It is closely related to euphemism and politeness, which will be discussed in a later section.

Next, I will focus on ways of using euphemisms for the purpose of politeness. Voßhagen (1999) indicates the case of the "pretty ear" that represents "an ear deformed from being hit repeatedly; a cauliflower ear" (Wentworth and Flexner, 1967). The word "pretty" is used to express the adjective "ugly," but to avoid mentioning something negative and that is a socially marked term, a desirable opposite and unmarked expression is deliberately used to illustrate something with a negative evaluation. One of Voßhagen's major proposals is that evaluative concepts show a different kind of asymmetry. Whereas the markedness of physical measurement antonyms is perceptually motivated, evaluative antonyms involve what may be said to be a socially motivated markedness. The adjectives that express a socially desirable, positive concept may be called unmarked, whereas those that express a negative, socially undesirable concept may be regarded as marked (Voßhagen, 1999, p. 295). This can be said to be a reflection of politeness. People sometimes avoid using direct expressions for various reasons. For example, in the Bible, Exodus, Chapter 20, Verse 7, Moses states in the Decalogue (the Ten Commandments): "Thou shalt not take the name of the LORD thy God in vain: for the LORD will not hold him guiltless that taketh his name in vain." (Authorized King James Version, Exodus. 20.7). According to this belief, Christians often avoid stating God's name in vain out of respect for God. 
In addition, in Japan, department stores often have special secret sign music to indicate rain, theft, or suspicious individuals. Only the clerks of the department stores know the link between the meaning of certain music and the desirable action. For instance, if it is raining, the shopping bags will get wet. To offer a better service, clerks cover paper shopping bags with plastic, even though the clerks cannot generally see the outside view from the shops inside the department stores. Therefore, the stores use the music to tell the clerks that it is raining outside, and the clerks interpret it as an order to cover the paper shopping bags with plastic without letting the customers know that they are offering a better service. For safety reasons, to protect against theft or suspicious individuals, such music is also used. Furthermore, they even have secret code words to express "I'm going to the restroom" without literally mentioning it. "I'm going to the number 5" might mean he/she is going to the restroom. Staff at amusement parks sometimes encounter situations involving vomit, and they express such situations in different or positive ways such as "a public rainbow."

\subsection{Metonymy, Politeness and the Reference-Point Construction}

It is interesting that metonymies are usually analyzed in the light of prominence by employing cognitive diagrams, such as the reference-point construction by Langacker (1993), whose analysis covers most realms of metonymy.

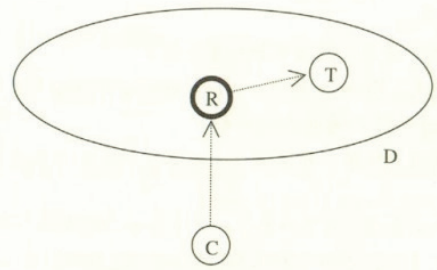

Conceptualizer (C) wants to focus on target (T), but it is sometimes difficult to directly reach the target. Therefore people choose to access the easier and more prominent factor, reference point $(R)$, and via reference $(R)$, conceptualizer $(\mathrm{C})$ focuses on target $(\mathrm{T})$. The arrows in the diagram show the mental path, and the letter D means the dominion, in other words, the accessible area via the reference point. The reference point is salient and has a profile. Langacker (1993) states the general principles of profiles as follows: 
(41) a. human > non-human

b. whole $>$ part

c. concrete $>$ abstract

d. visible $>$ non-visible

When employing Langacker's view in analyzing THE PLACE FOR THE EVENT-type metonymies, obviously the "whole > part" does not apply to THE PLACE FOR THE EVENT-type metonymies. The name of the place is only part of the event. However, it does not violate the "concrete > abstract" or the "visible > non-visible."

This paper states that the characteristics of THE PLACE FOR THE EVENT-type metonymies are those which (1) mainly express NEGATIVE events; (2) a part (name of the place) is chosen to express the whole (the whole event), which is a violation in Langacker's view; (3) people prefer to avoid fully and concretely describing negative events, since it hurts people's feelings; and (4) the choice of a part (name of the place) over the whole (the whole event) is sufficient, since negative evaluative factors are linguistically and psychologically prominent enough to successfully convey the euphemistic connotation.

Kövecses and Radden (1998) also demonstrate how people select the metonymic expressions as shown below.

(42) human over non-human/ concrete over abstract/ interactional over non-interactional/ functional over non-functional

(43) immediate over non-immediate/ occurrent over non-occurrent/ more over less/ dominant over less dominant/ good gestalt over poor gestalt/ bounded over unbounded/specific over generic

(44) stereotypical over non-stereotypical/ ideal over non-ideal/ typical over non-typical/ central over peripheral/ basic over non-basic / important over less important/ common over less common/ rare over less rare

(45) clear over less clear

(46) relevant over irrelevant 
According to the above, using THE PLACE FOR THE EVENT-type metonymies follows some of these principles such as "concrete over abstract" and "relevant over irrelevant."

Clearly, THE PLACE FOR THE EVENT-type metonymies violate Grice's (1975, p. 41-58) cooperative principle, especially the maxim of quantity and the maxim of manner, since some people in the world would never understand what the name Fukushima or Hiroshima metonymically means, and the literal expression (name of the place) is too partial to imagine the whole event referred to in the literal expression (name of the place). At the same time, it would be more polite and practical to choose these metonymic expressions than to fully and concretely describe the entire event at Fukushima or Hiroshima. From the pragmatics and politeness point of view, in order to give sufficient consideration and in order not to be offensive toward the listener, the speaker prefers a non-negative expression. As human beings living through social interactions, we naturally try to avoid conflicts that may cause problems and thus decrease one's own benefit. Negative evaluative events are salient but can be too socio-culturally impolite/ sorrowful/painful even to be mentioned through an obvious expression.

Moreover, events consist of countless factors, and personal factors differ from person to person. It is therefore impossible to fully and concretely describe the whole event in words. Events are something experienced by human beings, and each human being experiences events similarly and differently; their experience is never identical. Therefore, these metonymic expressions are useful in conveying the connotations that are beyond literal description.

\section{Conclusions}

THE PLACE FOR THE EVENT-type metonymy is one of the expressions related to politeness and euphemism. Interestingly enough, metonymic expressions use the reference point to reach and express the target, and the reference point is generally salient and prominent, but THE PLACE FOR THE EVENT-type metonymy uses the name of the place as the reference point, and the image of the intended meaning and interpretation of the whole event can differ from person to person. In other words, some metonymic expressions are translatable and comprehensible in other languages (for example, Professor Maria Lúcia Coutinho Colen tickled 
the ivories= to play the piano), but THE PLACE FOR THE EVENT-type metonymies are highly contextually based and affected by the speaker's/ hearer's background knowledge.

This paper has presented four main characteristics of THE PLACE FOR THE EVENT-type metonymies. First, THE PLACE FOR THE EVENT-type metonymies mainly express NEGATIVE events. Second, in this type of metonymy, a part (name of the place) is chosen to express the whole (the whole event). Third, people avoid fully and concretely describing negative events in order not to hurt the other person's feelings or the speaker's feelings. Lastly, negative evaluative factors are linguistically and psychologically so prominent and marked that people can use a part (name of the place) to refer to the whole (the whole event), and successfully convey euphemistic connotations.

\section{References}

ALBEE, E. Who's Afraid of Virginia Woolf. Harmondsworth: Penguin, 1962.

BARNDEN, J. A. Metaphor and Metonymy: Making Their Connections More Slippery. Cognitive Linguistics, Berlin/New York, v. 21, n. 1, p. 1-34, March, 2010. DAHL, Ö. Typology of Sentence Negation. Linguistics, the Hague, v. 17, p. 79106, 1979.

DIRVEN, R. Metonymy and Metaphor: Different Mental Strategies of Conceptualization. In: DIRVEN, René and PÖRINGS, Ralf (Eds.). Metaphor and Metonymy in Comparison and Contrast. Berlin/New York: Mouton de Gruyter, 2002. p. 75-111.

EGAMI, N.; YAMAMOTO, T.; HAYASHI, K.; NARUSE, O. Shosetsu Sekaishi (Detailed World History). Tokyo: Yamakawa Publishing Co., 1997.

EKMAN, P.; LEVENSON, R.W.; FRIESEN, W. V. Autonomic nervous system activity distinguishes among emotions. Science. Washington, D. C., v. 221, p. 1218-1220, 1983.

GOOSSENS, L. Metaphtonymy: The Interaction of Metaphor and Metonymy in Figurative Expressions for Linguistic Action. In: GOOSSENS, Louis et al. By Word of Mouth. Amsterdam and Philadelphia: John Benjamins, 1995. p. 159-174.

GRICE, P. H. Logic and Conversation. In: COLE, Peter and MORGAN, Jerry (Eds.). Syntax and Semantics, New York, 1975. p. 41-58.

HASER, V. Metaphor, Metonymy and Experientialist Philosophy: Challenging Cognitive Semantics. Berlin/New York: Mouton de Gruyter, 2005. 
HAYAKAWA, S. Language in Thought and Action. $4^{\text {th }}$ ed. New York: Harcourt Brace Jovanovich, 1939 [1978].

HORN, L. R. A Natural History of Negation. Chicago: The University of Chicago Press, 1989.

JAKOBSON, R. The Metaphoric and Metonymic poles. In: DIRVEN, René and PÖRINGS, Ralf (Eds.). Metaphor and Metonymy in Comparison and Contrast, Berlin/New York: Mouton de Gruyter, 2002 [1956]. p. 41-47. Reprinted with added abstract by René Dirven from Roman Jakobson and M. Halle (eds.). Fundamentals of Language, The Hague and Paris, v. 2, p. 90-96, 1971 [1956].

JESPERSEN, O. Negation in English and Other Languages. Copenhagen: Host, 1917.

JING-SCHUMIDT, Z. Negativity bias in Language: A cognitive-affective model of emotive intensifiers. Cognitive Linguistics, Berlin/New York, v. 18, n. 3, p. 417443, 2007.

KÖVECSES, Z.; RADDEN, G. Metonymy: Developing a Cognitive Linguistics View, Cognitive Linguistics, Berlin/ New York, v. 9, n. 1, p. 37-77, 1998.

LADUSAW, W. A. Negation, Indefinites, and the Jespersen Cycle, Berkeley: In the Proceedings of the Nineteenth Annual Meeting of the Berkeley Linguistics Society: General Session and Parasession on Semantic Typology and Semantic Universals, 1993. p. 437-446.

LAKOFF, G.; JOHNSON, M. Metaphors We Live By. Chicago: The University of Chicago Press, 1980.

LANDIS, T. Y.; HERRMANN, D. J.; CHAFFIN, R. Developmental differences in the comprehension of semantic relations. Zeitschrift für Psychologie, Leipzig, v. 195, p. 129-139, 1987.

LANGACKER, R. W. Reference-point constructions. Cognitive Linguistics, Berlin/ New York, v. 4, p. 1-38, 1993.

LODGE, D. The Modes of Modern Writing: Metaphor, Metonymy and the Typology of Modern Literature. London: Edward Arnold; Ithaca: Cornell University Press, 1977. NANNEY, E (Project Coordinator). History Year by Year. London: Dorling Kindersley Limited, 2011.

NERLICH, B.; CLARKE, D. D. Synecdoche as a Cognitive and Communicative Strategy. In: BLANK, A. and KOCH, P. (Eds.). Historical Semantics and Cognition, Berlin/New York: Mouton de Gruyter, 2001. p. 197-214.

NORRICK, N. R. Semiotic Principles in Semantic Theory. Amsterdam: John Benjamins, 1981. 
NUMBERG, G. The Pragmatics of Reference. Bloomington: Indiana University Linguistics Club, 1978.

RADDEN, G. How Metonymic are Metaphors. In: BARCELONA, A. (Ed.). Metaphor and Metonymy at the Crossroad: A Cognitive Perspective. Berlin/New York: Mouton de Gruyter, 2000. p. 93-108.

RIEMER, N. Remetonomyzing Metaphor: Hypercategories in Semantic Extention. Cognitive Linguistics, Berlin/New York, v. 12, n. 4, p. 379-401, 2001.

VOßHAGEN, C. Opposition as a Metonymic Principle. In: UWE AND PANTHER, K.; RADDEN, G. (Eds.). Metonymy in Language and Thought. Amsterdam/Philadelphia: John Benjamins Publishing Company, 1999. p. 289-308.

WARREN, B. An Alternative Account of the Interpretation of Referential Metonymy and Metaphor. In: DIRVEN, R.; PÖRINGS, R. (Eds.). Metaphor and Metonymy in Comparison and Contrast. Berlin/New York: Mouton de Gruyter, 2002. p. 113-130.

WARREN, B. Referential metonymy. Stockholm: Almquiest and Wilksell International, 2006.

The Bible, Authorized King James Version, Oxford World's Classics, Oxford: Oxford University Press, 2008.

Data de submissão: 08/08/2014. Data de aprovação: 05/01/2015. 